Acta vet. scand. $1981,22,211-217$.

From the Department of Pharmacology and Toxicology, Veterinary College of Norway, Oslo.

\title{
TEMPERATURE RELATED ABSORPTION AND EXCRETION OF SULPHADIMIDINE IN RAINBOW TROUT, SALMO GAIRDNERI
}

By

Anne Borgan, Stig Ødegaard and Torill Bergsjø

BORGAN, A., S. ØDEGAARD and T. BERGSJ $\emptyset$ : Temperature related absorption and excretion of sulphadimidine in rainbow trout, Salmo gairdneri. Acta vet. scand. 1981, 22, 211-217. - The main purpose of the present study was to see if a kinetic model and a computer program for characterizing the rate of uptake and clearance of chemicals in aquatic organisms (Biofac, OECD's Chemicals Testing Programme) was applicable to pharmacokinetic studies in fish. The program seems suitable for such studies.

The effect of temperature upon rate of absorption of sulphadimidine from medicated water and elimination of the same drug was investigated in rainbow trout. $A$ rise in the temperature from $7^{\circ} \mathrm{C}$ to $14^{\circ} \mathrm{C}$ more than doubled the calculated rate constants of absorption and elimination. The biological half life $\left(t_{1 / 2} \beta\right)$ and the time to reach $90 \%$ of steady state $\left(t_{90} \% s s\right)$ at $14^{\circ} \mathrm{C}$ were approximately half the values at $7^{\circ} \mathrm{C}$.

absorption; elimination; pharmacokinetic parameters; fish; drug; temperature; computer prog r a m.

OECD - Chemicals Testing Programme includes a kinetic model and a computer program for characterizing the rate of uptake and clearance of chemicals in aquatic organisms. This program is recommended for use in all countries participating in the program. Its application is generally directed to the study of bioaccumulation of chemicals in environmental toxicology.

The purpose of this study was to see if the program is suitable for similar pharmacological studies.

It is known that alterations in parameters such as water $\mathrm{pH}$ (Bergsjф \& Bergsjф 1978), salt concentration (Bergsjф \& Sфgnen 1980) and temperature (Dalgaard-Mikkelsen \& Rasmussen 1964, 
Herman \& Degurse 1967, Ljungberg et al. 1969) is of importance for kinetics of drugs in fish. Temperature alteration also influences the uptake of environmental contaminants (Cairns et al. 1975, Kaka \& Hayton 1978).

In fish farming it may be possible and necessary to treat fish diseases by dissolving the drug in the water. Under such conditions the variations in temperature may be great. This study was carried out also in order to provide a pharmacokinetic description of the uptake and excretion of one of the sulphonamides used in practical therapy in fish.

\section{MATERIAL AND METHODS}

One hundred rainbow trout (Salmo gairdneri), each weighing approximately $100 \mathrm{~g}$ were divided into two groups and placed into $400 \mathrm{l}$ tanks of fresh water. The temperatures were $7^{\circ} \mathrm{C}$ and $14^{\circ} \mathrm{C}$, respectively and the $\mathrm{pH} 6.8$. Air was provided by bubbling and the water flow was $0.3 \mathrm{l} / \mathrm{min}$. Following adaptation to the two temperatures, the flow was discontinued and sulphadimidine added. The addition of drug caused the water $\mathrm{pH}$ to rise to 8.0. Heparinized blood samples were obtained from four random fish from each tank at intervals $6,12,24,30,48$ and $72 \mathrm{~h}$ after the drug was added. After $72 \mathrm{~h}$ the water was replaced with sulphafree water ( $\mathrm{pH} \mathrm{6.8)} \mathrm{and} \mathrm{the} \mathrm{original} \mathrm{water} \mathrm{flow} \mathrm{was} \mathrm{resumed.}$ During the elimination phase blood samples were taken from four random fish at $78,96,120,144,168$ and $192 \mathrm{~h}$ following the addition of sulphadimidine to water. Prior to blood sampling the fish were anesthetized by $\mathrm{CO}_{2}$ which was produced by dissolving $\mathrm{NaHCO}_{3}$ and tartaric acid in luke warm water. The fish were not fed during the experimental period and no mortalities occurred.

The concentrations of sulphonamide at the beginning of the experiment were 1044 and $904 \mathrm{mg} / \mathrm{l}$ water, and $72 \mathrm{~h}$ later 1064 and $916 \mathrm{mg} / \mathrm{l}$ in the $7^{\circ} \mathrm{C}$ and $14^{\circ} \mathrm{C}$ tanks, respectively. During the elimination phase the flow of fresh water was adequate to maintain the sulphadimidine concentration at undetectable levels.

The blood concentrations of sulphadimidine and acetylsulphadimidine were measured by high-performance liquid chromatography (HPLC). To $250 \mu$ l of whole blood was added an equal volume of water, and proteins were denaturated by mixing on a 
whirlimixer and simultaneous addition of $500 \mu \mathrm{l}$ acetonitrile $\left(\mathrm{CH}_{3} \mathrm{CN}\right)$. The samples were centrifuged after $30 \mathrm{~min}$ and $25 \mu \mathrm{l}$ of the supernatants were injected into a HPLC. A solution of acetonitrile and distilled water $(24 / 76, \mathrm{v} / \mathrm{v})$ to which $0.4 \%$ triethylamine was added, was used as the mobile phase. This solution was adjusted to $\mathrm{pH} 3.8$ using phosphoric acid $\left(\mathrm{H}_{3} \mathrm{PO}_{4}\right)$. Separation was accomplished by using a reversed phase column (Radpac A, Waters Assoc.) and the UV-absorption was measured at $254 \mathrm{~nm}$ (Waters model 440). External standard quantitation by peak area was made on a Waters Data Module 730. Sample values are the means of two injections. The standard was run three times for every fifth duplicate injection of the samples.

The pharmacokinetic parameters were calculated using the BIOFAC computer program (Blau \& Agin 1978).

\section{RESULTS}

The blood concentrations of sulphadimidine and acetylsulphadimidine in individual fish taken at various intervals from the $7^{\circ} \mathrm{C}$ and $14^{\circ} \mathrm{C}$ tanks are shown in Figs. $1 \mathrm{~A}$ and 1B. The theoretical curves for blood concentration of sulphadimidine were calculated on the basis of the rate constants for absorption and elimination $\left(k_{1}\right.$ and $\left.k_{2}\right)$. The figure shows that both absorption and elimination rates were greatest at $14^{\circ} \mathrm{C}$. The calculated rate constants were more than doubled from $14^{\circ} \mathrm{C}$ to $7^{\circ} \mathrm{C}$ (Table 1 ). The biological half life $\left(t_{1 / 2} \beta\right)$ and the time to reach $90 \%$ of steady state $\left(\mathrm{t}_{90} \%\right.$ ss $)$ at $14^{\circ} \mathrm{C}$ were approximately half the values at $7^{\circ} \mathrm{C}$. Acetylsulphadimidine accounted for $8.6 \%$ and $7.4 \%$ of the total

T a b l e 1. Calculated pharmacokinetic parameters $( \pm s)$ for absorption from medicated fresh water and elimination of sulphadimidine in rainbow trout at $7^{\circ} \mathrm{C}$ and $14^{\circ} \mathrm{C}$.

\begin{tabular}{lll}
\hline & \multicolumn{2}{c}{ Temperature } \\
\cline { 2 - 3 } & \multicolumn{1}{c}{$7^{\circ} \mathrm{C}$} & \multicolumn{1}{c}{$14^{\circ} \mathrm{C}$} \\
\hline $\mathrm{k}_{1}$ & $0.0019 \pm 0.0003 \mathrm{t}^{-1}$ & $0.0080 \pm 0.0007 \mathrm{t}^{-1}$ \\
$\mathrm{k}_{2}$ & $0.0134 \pm 0.0017 \mathrm{t}^{-1}$ & $0.0282 \pm 0.0020 \mathrm{t}^{-1}$ \\
$\mathrm{t}_{1 / 2 \beta}$ & $51.7 \pm 6.4 \mathrm{t}$ & $24.6 \pm 1.8 \mathrm{t}$ \\
$\mathrm{t}_{90 \% \text { ss }}$ & $171.9 \pm 21.2 \mathrm{t}$ & $81.8 \pm 5.9 \mathrm{t}$ \\
\hline
\end{tabular}

$k_{1}$ and $k_{2}=$ rate constants for absorption and elimination, $t_{1 / 2} \beta=$ biological half life, and $t_{90 \% s s}=$ time to reach $90 \%$ of steady state. 

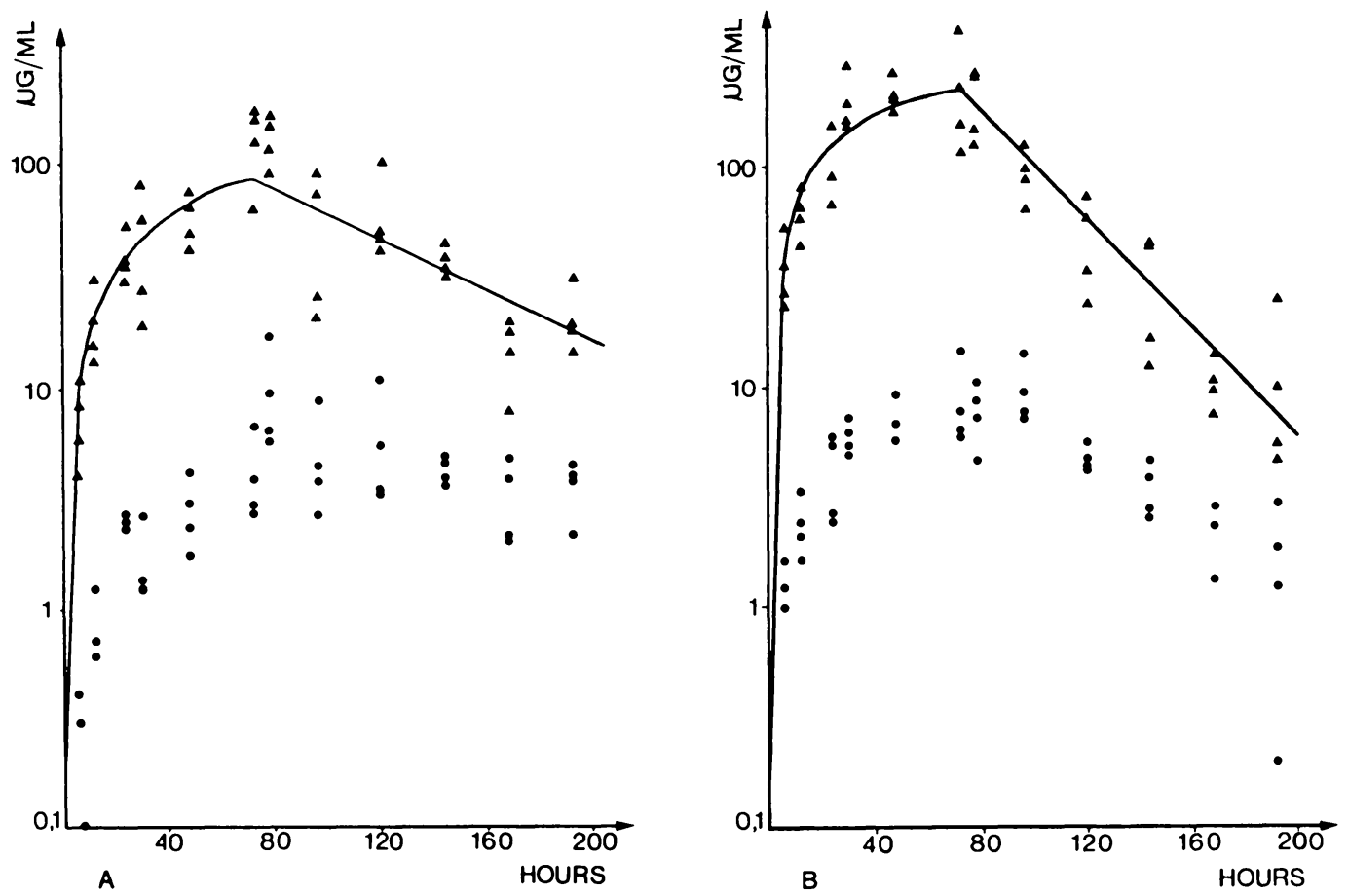

F i g u re 1. Concentration of sulphadimidine $(\Delta)$ and acetylsulphadimidine $(O)$ in whole blood from rainbow trout during absorption and elimination phases. Solid curves are computer-simulated levels of sulphadimidine, based on individual observations and a pharmacokinetic model.

Water temperature: $\mathrm{A}: 7^{\circ} \mathrm{C}, \mathrm{B}: 14^{\circ} \mathrm{C}$.

sulpha of fish at $7^{\circ} \mathrm{C}$ and $14^{\circ} \mathrm{C}$, respectively. Toward the end of the experiment this metabolite accounted for an increasing proportion of the total sulpha.

\section{DISCUSSION}

The absorption of dissolved drug by freshwater fish is presumably accomplished by passive diffusion via the gills according to first order kinetics. Elimination of the parent compound can be accomplished via diffusion from the gills to water, via the kidneys and as a result of metabolic processes. Metabolism is also usually governed by first order kinetics. The computer program BIOFAC is based upon compartment models (Blau et al. 1975, Branson et al. 1975) which assume first order kinetics. 
The theoretical equation for concentration of drugs in fish blood at time $t, C(t)$, is

$$
\begin{array}{ll}
\mathrm{C}(\mathrm{t})=\mathrm{C}_{\mathrm{w}} \frac{\mathrm{k}_{1}}{\mathrm{k}_{\mathbf{2}}}\left(1-\mathrm{e}^{-\mathbf{k}_{\mathbf{2}} \mathrm{t}}\right) & 0 \leq \mathrm{t} \leq \mathrm{t}^{*} \\
\mathrm{C}(\mathrm{t})=\mathrm{C}_{\mathrm{w}} \frac{\mathrm{k}_{1}}{\mathrm{k}_{\mathbf{2}}}\left(\mathrm{e}^{-\mathrm{k}_{\mathbf{2}}\left(\mathrm{t}-\mathrm{t}^{*}\right)}-\mathrm{e}^{-\mathrm{k}_{\mathbf{2}} \mathrm{t}}\right) & \mathrm{t} \geq \mathrm{t}^{*}
\end{array}
$$

where $C_{w}$ is drug concentration in water, $k_{1}$ and $k_{2}$ are rate constants for absorption and elimination, respectively, and $t^{\star}$ is the time when the fish are transferred to drug-free water.

It can be seen in Fig. 1 that there could be large variations in fish sampled at the same time, something which is due to individual biological variation. However, variations in hematocrit could influence the measurements since whole blood was used in the analyses.

The statistical analyses are based upon a model which assumes first order kinetics and which furthermore takes into account that the variance is larger at higher concentrations. With repeated measurements at each time point it is possible to assess the fitness of the model. An approximated F-test for the assumption of first order kinetics, as well as the assumption on the variance of the measurements as discussed by Reilly \& Blau (1974) and by Reilly et al. (1977) was utilized. The fitness of the model was good for fish kept at $14^{\circ} \mathrm{C}$ where $\mathrm{F}=0.82$ (d.f. $=$ 10 and 36 ), but at $7^{\circ} \mathrm{C}$ the $\mathrm{F}$ value was 2.2 (d.f. $=10$ and 36 ) indicating a poor fit. Plot of the logarithm of the variance versus the logarithm of the calculated concentration at each time point gave a reasonably linear relationship for both $7^{\circ} \mathrm{C}$ and $14^{\circ} \mathrm{C}$. 'This indicates that the poor fit at $7^{\circ} \mathrm{C}$ is not due to an incorrect assumption concerning the variances of the observed concentrations, but might be due to some variation in the physical environment. The water temperature was measured each time blood samples were taken, and in the $14^{\circ} \mathrm{C}$ tank it was constant during the entire experiment, whereas there were variations in the other tank ranging from 6.0 to $8.5^{\circ} \mathrm{C}$. These variations probably contribute to the poor fit for the lowest temperature. If this is the case then it illustrates the necessity of maintaining constant physical conditions in studies of this type. Furthermore, a small increase in the concentration of sulphadimidine in the water during the absorption phase probably reflects evaporative loss, but this could hardly influence the results. 
It is well known that diffusion as well as metabolism in poikilothermic organisms accelerates with increasing temperature. An increase of $1^{\circ} \mathrm{C}$ produces a corresponding increase in metabolism of about $10 \%$. Accordingly, the results correspond with the expectations. Therefore, in the endeavor to establish practical methods for medical treatment of fish using dissolved drugs, it is obvious that temperature is a critical variable. Irregardless as to the route used for applying the drugs, the environmental temperature is highly important for the kinetics, the duration of the therapeutic concentration and for the establishment of a deadline when the fish can be used for human consumption.

Several studies of sulphonamides in fish have detected hydrolysable conjugates which are referred to as acetylated sulpha. In the present study a peak appeared in the chromatogram, which, under different separation conditions, had exactly the same retention time as the $\mathrm{N}_{4}$-acetylsulphadimidine standard. Even if this cannot be considered as a definite identification, it nevertheless is a good indication that the metabolite is the $\mathrm{N}_{4}$ acetylated sulpha.

\section{ACKNOWLEDGEMENT}

The authors are indebted to Mr. $\emptyset$. Borgan for discussions on statistical problems.

\section{REFERENCES}

Bergsjø, T. \& T. H. Bergsj $\varnothing$ : Absorption from water as an alternative method for the administration of sulphonamides to rainbow trout, Salmo gairdneri. Acta vet. scand. 1978, 19, 102-109.

Bergsjф, T. \& E. Sфgnen: Plasma and tissue levels of trimethoprim in rainbow trout, Salmo gairdneri, after absorption from fresh and salt water. Acta vet. scand. 1980, 21, 18-25.

Blau, G. E. \& G. L. Agin: A users manual for BIOFAC: A computer program for characterizing the rates of uptake and clearance of chemicals in aquatic organisms. Dow Chemical Company, Midland 1978, pp. 12.

Blau, G. E., W. B. Neely \& D. R. Branson: Ecokinetics: A study of the fate and distribution of chemicals in laboratory ecosystems. AIChE Journal 1975, 21, 854-861.

Branson, D. R., G. E. Blau, H. C. Alexander \& W. B. Neely: Bioconcentration of $2,2^{\prime}, 4,4^{\prime}$,-tetrachlorobiphenyl in rainbow trout as measured by an accelerated test. Trans. Amer. Fish. Soc. 1975, 104, 785-792. 
Cairns, J. Jr., A. G. Heath \& B. C. Parker: Temperature influence on chemical toxicity to aquatic organisms. J. Water Poll. Contr. Fed. 1975, 47, 267-280.

Dalgaard-Mikkelsen, Sv. \& C. J. Rasmussen: Restkoncentrationer af sulfamerazin i $\varnothing$ rreder efter furunkulose-behandling. (Residues of sulfamerazine in trout after treatment for furunculosis). Nord. Vet.-Med. 1964, 16, 473-479.

Herman, R. L. \& P. E. Degurse: Sulfamerazine residues in trout tissues. Ichtyologica 1967, 39, 73-79.

Kaka, J. S. \& W. L. Hayton: Temperature and surfactant dependence of accumulation of 4-aminoantipyrine and ethanol in fish. J. pharm. Sci. 1978, 67, 1558-1563.

Ljungberg, O., S. Silven \& N. Johansson: Residues of sulphamerazine and terramycin in artificially fed rainbow trout. Symp. World Assoc. Veterinary Foodhygienist. Proceedings. Opatija, Sept. 22-27. 1969 , p. 565-570.

Reilly, P. M. \& G. E. Blau: The use of statistical methods to build mathematical models of chemical reacting systems. Canad. J. chem. Eng. 1974, 52, 289—299.

Reilly, P. M., R. Bajramovic, G. E. Blau, D. R. Branson \& M. W. Sauerhoff: Guidelines for the optimal design of experiments to estimate parameters in first order kinetic models. Canad. J. chem. Eng. 1977, 55, 614-622.

\section{SAMMENDRAG}

Absorpsjon og eliminasjon av sulfadimidin hos regnbue $\phi r r e t$, Salmo gairdneri, relatert til temperatur.

Hensikten med dette fors $\emptyset$ ket var å undersøke om den kinetiske modellen som er anbefalt av OECD's Chemicals Testing Programme er anvendbar på farmakokinetiske studier på fisk. Til denne modellen er det skrevet et computerprogram (Biofac) som beregner hastighetskonstantene for opptak og utskillelse av kjemikalier $i$ organismer i vann. Programmet synes å passe til studier av denne type, men konstante fors $\varnothing \mathrm{ksb}$ etingelser er avgjørende for å oppnå god tilpasning til modellen.

Temperaturens innvirkning på absorpsjonen av sulfadimidin fra vann og eliminasjonen av samme stoff ble unders $\varnothing \mathbf{k t}$ for regnbue $\varnothing$ rret. En heving av temperaturen fra $7^{\circ} \mathrm{C}$ til $14^{\circ} \mathrm{C}$ gav mer enn fordobling av kalkulerte hastighetskonstanter for absorpsjon og eliminasjon. Halveringstid $\left(t_{1 / 2} \beta\right)$ og tid for oppnådd $90 \%$ av steady state $\left(t_{90 \% \text { ss }}\right)$ var omtrent halvert ved $14^{\circ} \mathrm{C}$ sammenlignet med $7^{\circ} \mathrm{C}$.

(Received January 5, 1981).

Reprints may be requested from: Anne Borgan, the Department of Pharmacology and Toxicology, Veterinary College of Norway, P.O. Box 8146, Dep., Oslo 1, Norway. 